\title{
A STUDY OF PARTIAL REPLACEMENT OF FISH MEAL WITH SUNFLOWER MEAL ON GROWTH, AMINO ACID RETENTION, AND BODY COMPOSITION OF SHARPSNOUT SEABREAM, DIPLODUS PUNTAZZO (ACTINOPTERYGII: PERCIFORMES: SPARIDAE)
}

\author{
Silvia NOGALES MÉRIDA, Miguel JOVER CERDÁ, Silvia MARTÍNEZ LLORENS, \\ and Ana TOMÁS VIDAL*
}

Institute of Animal Science and Technology, Group of Aquaculture and Biodiversity

and Polytechnic University of Valencia

\begin{abstract}
Nogales Mérida S., Jover Cerdá M., Martínez Llorens S., Tomás Vidal A. 2011. A study of partial replacement of fish meal with sunflower meal on growth, amino acid retention, and body composition of sharpsnout seabream, Diplodus puntazzo (Actinopterygii: Perciformes: Sparidae). Acta Ichthyol. Piscat. 41 (1): 47-54.
\end{abstract}

\begin{abstract}
Background. Our previous study demonstrated that sharpsnout seabream, Diplodus puntazzo (Walbaum, 1792), can be fed with up to $34.8 \%$ sunflower meal (SFM), with excellent results in growth parameters and feed efficiency. The aim of the current study was to test the replacement of fish meal with SFM in the diet formulation for sharpsnout seabream and to evaluate growth, nutritive parameters, amino acid retention, and body composition of the fish during the fattening period.

Materials and methods. Sixteen baskets (300-L capacity), each with thirteen fish, were distributed in a recirculated saltwater system to allow four experimental diets containing $40 \%$ crude protein (CP) and 20\% crude lipid (CL) with $0 \%, 11.7 \%, 23.5 \%$, and $34.8 \%$ SFM partially replacing fish meal to be used in quadruplicate for this experiment. The fish were fed these diets ad libitum during the experiment, which lasted for 162 days. Growth, nutrition efficiency, biometrics, carcass composition, amino acid composition, and amino acid retention of the experimental fish were evaluated.

Results. There were no statistical differences in the growth parameters among the treatments. However, fish fed a diet containing $34.8 \%$ SFM had the lowest feed intake (FI), lowest feed conversion ratio (FCR), and the highest protein efficiency ratio (PER). There were also no statistical differences in the biometric parameters although fish fed the diet containing 10\% SFM had the lowest CP levels. Leucine was the only difference in the essential amino acid (EEA) profile with fish fed a diet containing 11.7\% SFM having the lowest levels of leucine. Although there were fluctuations among the amino acid retentions, they were not statistically significant.

Conclusion. SFM (up to $34.8 \%$ ) can be included in the diets of sharpsnout seabream, thereby, replacing $27 \%$ of the fish meal without altering the fish growth.
\end{abstract}

Keywords: Diplodus puntazzo, protein sources, sunflower meal (SFM), amino acid composition and retention

\section{INTRODUCTION}

Sharpsnout seabream, Diplodus puntazzo (Walbaum, 1792), are omnivorous fish of increasing interest in aquaculture production as an alternative product to gilthead seabream and sea bass in the European market, especially in Spain. In recent years, several researchers studying sharpsnout seabream in the fattening period before they reached market size documented that this species has a lower rate of weight increase than those reported for gilthead sea bream, but similar to sea bass (22 months) and Pagrus pagrus (20 months). Only three reports have described fish meal replacement by vegetal sources in sharpsnout seabream, such as replacement by soybean meal (Rondán et al. 2004, Hernández et al. 2007) and alfalfa meal (Chatzifotis et al. 2006).

According to Ahmad et al. (2004), sunflower meal (SFM) is an important by-product obtained following the extraction of oil from sunflower seeds used for livestock feed. SFM is a rich source of good quality protein that is available at a low price when compared with other sources of vegetal proteins. Sunflower seeds also contain a large amount of phenolic compounds, such as chlorogenic-, quinic-, and caffeic acids (Gandhi et al. 2008), but these substances may be reduced by common processing techniques, such as dry and wet heating, although heat treatment may decrease the nutritional quality of proteins

\footnotetext{
* Correspondence: Dr. Ana Tomás Vidal, Departamento de Ciencia Animal, Universidad Politécnica de Valencia, Camino de Vera, 14,46071 - Valencia, Spain, phone: 34-96-3879385, fax: 34-96-3877439, e-mail: atomasv@dca.upv.es.
} 
and carbohydrates (Francis et al. 2001). However, due to the absence of an effective dehulling process, the fibre content of sunflower seeds remains fairly high $(15 \%-24 \%)$ limiting the use of SFM in fish nutrition. The following maximal substitutions of SFM were obtained without statistical differences: $12 \%$ in gilthead seabream (Sánchez Lozano et al. 2007); 22\% in rainbow trout (Martínez 1984, Sanz et al. 1994); 60\% in tilapia (Furuya et al. 2000, Maina et al. 2003); and 20\% in Tilapia randalli fingerlings. Similarly, in Atlantic salmon, SFM substitution up to $33 \%$ was reported without any adverse effects on final fish weight (Gill et al. 2006). The metabolisable energy of SFM is low $\left(8371 \mathrm{~kJ} \cdot \mathrm{kg}^{-1}\right)$ when compared to other oil meals (Ahmad et al. 2004). According to Furuya et al. (2000), the limiting factors of sunflower meal utilisation in fish nutrition include high crude fibre (CF) content and a low lysine level.

The aim of this study was to evaluate if SFM protein could be used to replace fish meal in the diet formulation for sharpsnout seabream and to study the effects of these new diets on growth, nutrient utilisation, body composition and amino acid retention of the sharpsnout seabream.

\section{MATERIAL AND METHODS}

Sharpsnout seabream were obtained from an Italian commercial hatchery and were stocked in two cylindrical fibreglass tanks $(1750 \mathrm{~L})$ inside a recirculated seawater system. The fish were kept in these tanks and were fed $a d$ libitum with a diet containing $45 \%$ crude protein (CP) and $20 \%$ crude lipid (CL) for a month before the experiment started. The feeding trial was conducted at the aquaculture laboratory (Animal Science Department at the Polytechnic University of Valencia, Valencia, Spain). Two hundred and eight fish (average weight $106 \pm 1.7 \mathrm{~g}$ ) were randomly placed into sixteen baskets (300-L capacity) with two baskets per cylindrical fibreglass tank $(750 \mathrm{~L})$. The tanks were set up in a marine water recirculation system $\left(70 \mathrm{~m}^{3}\right.$ capacity) with a rotary mechanic filter and a gravity biofilter with an approximate capacity of $6 \mathrm{~m}^{3}$. All tanks were equipped with aeration, and the water was heated by a heat pump installed in the system. The following equipment was used to control water parameters: an oxymeter (OxyGuard, Handy Polaris V 1.26), a refractometer with 0\%-100\% capacity (Zuzi A67410) and a kit using the colorimetric method to determinate nitrate $\left(\mathrm{NO}_{3}-\mathrm{N}\right)$, ammonia $\left(\mathrm{NH}_{3}-\mathrm{N}\right)$ and nitrite nitrogen $\left(\mathrm{NO}_{2}-\mathrm{N}\right)$. The kits were obtained from AquaMerck (Merck KGaA, Darmstadt, Germany). The water temperature $\left(22.29 \pm 3.7^{\circ} \mathrm{C}\right)$ and dissolved oxygen $\left(6.04 \pm 0.7 \mathrm{mg} \cdot \mathrm{L}^{-1}\right)$ were measured daily. The salinity $\left(30.05 \pm 4.3 \mathrm{~g} \cdot \mathrm{L}^{-1}\right)$, $\mathrm{pH}(6.7 \pm 1.0), \mathrm{NH}_{3}-\mathrm{N}\left(0.05 \pm 0.1 \mathrm{mg} \cdot \mathrm{L}^{-1}\right), \mathrm{NO}_{2}-\mathrm{N}$ $\left(0.34 \pm 0.2 \mathrm{mg} \cdot \mathrm{L}^{-1}\right)$, and $\mathrm{NO}_{3}-\mathrm{N}\left(41.1 \pm 33.7 \mathrm{mg} \cdot \mathrm{L}^{-1}\right)$ were measured three times a week. The photoperiod was natural, and all tanks had similar light conditions. Each experimental diet was tested in quadruplicate.

Four experimental diets were formulated (Table 1), and each diet contained $45 \% \mathrm{CP}$, approximately $22.45 \mathrm{MJ} \cdot \mathrm{kg}^{-1}$ of energy and one of the four levels of SFM $(0 \%, 11.7 \%$, $23.5 \%$, and $34.8 \%$ ). The $11.7 \%, 23.5 \%$, and $34.8 \%$ SFM inclusion levels were calculated for replacing the following levels of fish meal: $8.8 \%, 17.7 \%$, and $27 \%$, respectively. While preparing the diets, wheat and SFM were ground to a fine particle size in a hammer mill (Technochufa, Valencia, Spain). All ingredients were then thoroughly mixed with vitamins and minerals. The diets were prepared by extrusion cooking with a semiindustrial twin-screw extruder (Clextral BC-45, St. Etienne, France), which helped to destroy harmful microorganisms while minimising the loss of nutrients or flavours. The processing conditions were as follows: 100 rpm screw speed, $110^{\circ} \mathrm{C}$ temperature, 4053-5066-kPa pressure and 2-3 $\mathrm{mm}$ diameter pellets according to fish size. The diets were stored in plastic buckets at room temperature until they were fed to the fish. All diets were

Table 1

Ingredients composition of the experimental diets tested on sharpsnout seabream, Diplodus puntazzo

\begin{tabular}{lcccc}
\hline Ingredient $\left[\mathrm{g} \cdot \mathrm{kg}^{-1}\right]$ & $0 \% \mathrm{SFM}$ & $11.7 \mathrm{SFM}$ & $23.5 \mathrm{SFM}$ & 34.8 SFM \\
\hline Fish meal, herring & 603 & 550 & 496 & 440 \\
Sunflower meal & 0 & 117 & 235 & 348 \\
Wheat & 200 & 132 & 64 & 3 \\
Dextrine & 50 & 50 & 50 & 50 \\
Soybean oil & 46 & 46 & 46 & 46 \\
Fish oil & 91 & 95 & 69 & 103 \\
Vitamin mix & 6.3 & 6.3 & 2.2 & 6.3 \\
Mineral mix & & 2.2 & 1.5 & 2.2 \\
Vitamin C & 1.5 & 1.5 & 1.5 \\
\hline
\end{tabular}

${ }^{\mathrm{a}}$ The vitamin mix (values are $\mathrm{g} \cdot \mathrm{kg}^{-1}$ except to those in parenthesis) included the following:, 20; Choline, 10; DL- $\alpha$-tocopherol, 5 ; and ascorbic acid, 5. retinol acetate (1 $\left.000000 \mathrm{IU} \cdot \mathrm{kg}^{-1}\right)$; calciferol $\left(500 \mathrm{IU} \cdot \mathrm{kg}^{-1}\right)$; DL- $\alpha$-tocopherol, 10; menadione sodium bisulphite, 0.8 ; thiamin hydrochloride, 2.3; riboflavin, 2.3; pyridoxine hydrochloride, 15; cyanocobalamin, 25; nicotinamide, 15; pantothenic acid, 6; folic acid, 0.65; biotin, 0.07; ascorbic acid, 75; inositol, 15; betaine, 100; and polypeptides; ${ }^{\mathrm{b}}$ The mineral mix included the following: $\mathrm{Zn}, 5 ; \mathrm{Se}, 0.02 ; \mathrm{I}, 0.5 ; \mathrm{Fe}, 0.2 ; \mathrm{Cu} 15 ; \mathrm{Mg}, 5.75 ; \mathrm{Co}, 0.02$; except to $1000 \mathrm{~g}$ (Source: Dibaq-Diproteg); $\mathrm{SFM}=$ sunflower meal. 
administered within three months of being manufactured.

The experiment lasted for 162 days (July 302008 through January 8 2009). The experimental diets were hand fed to the fish to apparent visual satiety twice daily $(0900 \mathrm{~h}$ and $1700 \mathrm{~h}$ ) for five days a week and just once on Saturday $(1000$ h). Feed intake (FI) was carefully monitored to minimise feed wastage.

During the experimental period, fish were fasted for $24 \mathrm{~h}$ followed by anaesthetisation with $30 \mathrm{mg} \cdot \mathrm{L}^{-1}$ of clove oil (Guinama, Valencia, Spain) containing 87\% Eugenol. The fish were bulk weighed and counted every three weeks, except at the beginning and end of the experiment when all fish were weighed individually.

Pooled samples of five fish from the initial stock population and four fish from each basket at the end of the experiment were taken to record the biometric parameters and were stored at $-20^{\circ} \mathrm{C}$ for subsequent whole body composition analyses.

Chemical analyses of the dietary ingredients were determined prior to diet formulation. The diets, ingredients in the diets and the whole fish were analysed according to AOAC (Anonymous 1990) procedures as follows: dry matter $\left(105^{\circ} \mathrm{C}\right.$ to constant weight); ash (incinerated at $550^{\circ} \mathrm{C}$ to constant weight); $\mathrm{CP}(\mathrm{N} \times 6.25)$ by the Kjeldahl method after acid digestion (Kjeltec 2300 Auto Analyser, Tecator, Höganas, Sweden); CL extraction with methyl ether (Soxtec 1043 extraction unit; Tecator); and CF by acid and basic digestion (Fibertec System M. 1020 Hot Extractor; Tecator). All analyses were performed in triplicate.

Following the method previously described by Bosch et al. (2006), the amino acids from fish carcasses and diets were analysed by a Waters HPLC system (Waters 474;

Table 2

Proximate composition and amino acid composition of ingredients and experimental diets tested on sharpsnout seabream, Diplodus puntazzo

\begin{tabular}{|c|c|c|c|c|c|c|c|}
\hline \multirow{2}{*}{\multicolumn{2}{|c|}{ Component }} & \multicolumn{6}{|c|}{ Diet } \\
\hline & & Fish meal & SFM & $0 \mathrm{SFM}$ & 11.7 SFM & 23.5 SFM & 34.8 SFM \\
\hline \multicolumn{2}{|c|}{ Dry matter $[\% \mathrm{DM}]$} & 92.84 & 90.00 & 92.43 & 92.89 & 93.37 & 94.26 \\
\hline \multicolumn{2}{|c|}{ Crude protein $[\% \mathrm{DM}]$} & 71.20 & 38.33 & 45.48 & 45.48 & 44.99 & 44.42 \\
\hline \multicolumn{2}{|c|}{ Crude lipid [\% DM] } & 9.98 & 2.17 & 20.84 & 20.92 & 21.53 & 21.02 \\
\hline \multicolumn{2}{|c|}{ Ash $[\% \mathrm{DM}]$} & 16.75 & 7.96 & 11.64 & 11.45 & 11.22 & 11.23 \\
\hline \multicolumn{2}{|c|}{ Crude fibre $[\%$ DM] } & 0 & 23.00 & 0.48 & 2.28 & 4.85 & 7.44 \\
\hline \multicolumn{2}{|c|}{ NFE $[\%$ DM $]$} & 0 & 28.5 & 21.55 & 19.87 & 17.40 & 15.89 \\
\hline \multicolumn{2}{|c|}{ Gross energy $\left[\mathrm{kJ} \cdot \mathrm{g}^{-1} \mathrm{DM}\right]$} & 20.99 & 15.04 & 22.96 & 22.69 & 22.38 & 21.78 \\
\hline \multicolumn{2}{|c|}{$\mathrm{CP} / \mathrm{GE}\left[\mathrm{g} \cdot \mathrm{MJ}^{-1}\right]^{\mathrm{c}}$} & 34.65 & 25.48 & 19.81 & 20.04 & 20.10 & 20.39 \\
\hline \multirow{9}{*}{ 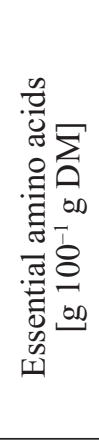 } & Arginine & 6.13 & 3.07 & 3.65 & 3.66 & 3.68 & 3.67 \\
\hline & Histidine & 2.64 & 1.09 & 1.50 & 1.48 & 1.46 & 1.44 \\
\hline & Isoleucine & 3.51 & 1.69 & 2.00 & 2.01 & 2.01 & 2.00 \\
\hline & Leucine & 5.62 & 2.42 & 3.33 & 3.29 & 3.24 & 3.18 \\
\hline & Lysine & 4.40 & 1.07 & 3.02 & 2.86 & 2.70 & 2.53 \\
\hline & Methionine & 1.61 & 0.59 & 1.23 & 1.18 & 1.14 & 1.09 \\
\hline & Phenylalanine & 4.89 & 2.32 & 2.33 & 2.37 & 2.41 & 2.44 \\
\hline & Threonine & 3.57 & 1.45 & 2.11 & 2.08 & 2.05 & 2.00 \\
\hline & Valine & 3.83 & 1.92 & 2.32 & 2.32 & 2.32 & 2.30 \\
\hline \multirow{8}{*}{ 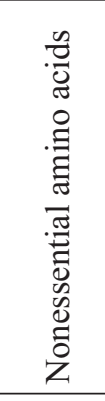 } & Alanine & 4.42 & 1.58 & 2.90 & 2.81 & 2.72 & 2.61 \\
\hline & Asparagine & 6.27 & 3.19 & 4.09 & 4.08 & 4.06 & 4.02 \\
\hline & Cystine & 1.00 & 1.17 & 0.85 & 0.90 & 0.95 & 0.99 \\
\hline & Glutamine & 8.92 & 6.95 & 6.14 & 6.26 & 6.39 & 6.48 \\
\hline & Glycine & 5.32 & 2.55 & 3.23 & 3.22 & 3.21 & 3.18 \\
\hline & Proline & 7.00 & 3.30 & 4.14 & 4.11 & 4.07 & 4.01 \\
\hline & Serine & 2.96 & 1.73 & 1.91 & 1.92 & 1.93 & 1.92 \\
\hline & Tyrosine & 3.57 & 0.97 & 1.72 & 1.67 & 1.63 & 1.57 \\
\hline \multicolumn{2}{|c|}{ EAA/NEAA } & 0.92 & 0.73 & 0.86 & 0.85 & 0.84 & 0.83 \\
\hline
\end{tabular}

a Nitrogen Free Extract (NFE) $\%=100-\mathrm{CP} \%-\mathrm{CL} \%-\mathrm{Ash} \%-\mathrm{CF} \%$; Crude Protein $(\mathrm{CP}) \%=($ titration volume for the sample $[\mathrm{mL}])$ - (titration volume for the blank $[\mathrm{mL}] \times 0.875) /$ sample weight $[\mathrm{g}]$; Crude Lipid $(\mathrm{CL}) \%=100 \times($ weight of beaker and fat residue $[\mathrm{g}]$ - weight of beaker [g] / initial sample weight [g]; Crude Fibre $\%=($ residue $[\mathrm{g}])-(\mathrm{ash}[\mathrm{g}])$; ${ }^{\mathrm{b}} \mathrm{GE}$; gross energy that was calculated using the following: $23.9 \mathrm{~kJ} \cdot \mathrm{g}^{-1}$ protein, $39.8 \mathrm{~kJ} \cdot \mathrm{g}^{-1}$ lipids and $17.6 \mathrm{~kJ} \cdot \mathrm{g}^{-1}$ carbohydrates; $\mathrm{SFM}=$ sunflower meal. 
Waters, Milford, MA, USA) consisting of two pumps (Model 515; Waters), an auto sampler (Model 717; Waters), a fluorescence detector (Model 474; Waters) and a temperature control module. Amino butyric acid was added as an internal standard pattern before hydrolysation. The amino acids were derivatised with 6-aminoquinolyl-N-hydroxysuccinimidyl carbamate (AQC). Methionine and cysteine were determined separately as methionine sulphone and cysteic acid after oxidation with performic acid. Amino acids were separated with a C-18 reversephase column (Waters Acc. Tag; $150 \mathrm{~mm}$ x $3.9 \mathrm{~mm}$ ) and were then transformed into methionine and cysteine.

The growth data and nutritive parameters were treated using multifactor analysis of variance (ANOVA) introducing the initial live weight as a covariate (Snedecor and Cochran 1971). The Newman-Keuls test was used to assess specific differences among diets at a significance level of $P<0.05$ (Statgraphics, Statistical Graphics System, Version Plus 5.1, Herndon, VA, USA).

All experiments were carried out according to the rules or protocols of the Animal Welfare Commission at the Polytechnic University of Valencia.

\section{RESULTS}

Experimental diets (Table 2) had well balanced levels of CP and CL. However, as a consequence of SFM inclusion in the diets, the $\mathrm{CF}$ increased from $0.5 \%$ through $7.4 \%$. The amino acid profiles of the experimental diets, irrespective of SFM inclusion, were similar. The relations between essential amino acids (EAA) and nonessential amino acids (NEAA) were also similar among the experimental diets $(0.89,0.88,0.93$, and 0.89 for $0 \%, 11.7 \%$, $23.5 \%$, and $34.8 \%$ SFM, respectively).

Fish survival was $88 \%(P<0.05)$ during the experimental period, and survival did not differ among groups.

During the experimental period, fish growth was homogeneous and was unaffected by SFM inclusion although this growth was not good enough due to the gradual reduction of temperature in the course of the trial.

The final weight (Fw) fluctuated from 253 to $266 \mathrm{~g}$, and the SGR values were similar in all treatments from $0.65 \%$ per day to $0.69 \%$ per day even though the thermal coefficient of growth (TCG) levels were almost equal in all diets (1.10 to 1.16) without statistical differences. Considering feed efficiency, only the feed intake ratio (FIR) was affected by SFM inclusion with fish fed 34.8\% SFM having the lowest value ( $1.52 \mathrm{~g} \cdot 100 \mathrm{~g}^{-1}$ fish / day). The other parameters did not have statistical differences among treatments $(P<0.05)$ (Table 3$)$.

In the biometric parameters, the only statistical difference was found in hepatosomatic index (HIS) with fish fed the diet containing $34.8 \%$ SFM having the lowest value (0.98). In mesenteric fat index (MFI), however, an inverse correlation was observed with SFM inclusion whereas CF and viscerosomatic index (VSI) were not affected by the treatments (Table 3 ).

In Table 4, the CP content was the only value affected by SFM with fish fed the diet containing $11.7 \%$ SFM having the lowest value (17.78) with a statistical difference. The fish fed diet with $11.7 \%$ SFM had a higher moisture

Table 3

Growth performance, feed efficiency, and biometric parameters of sharpsnout seabream, Diplodus puntazzo, fed experimental diets ( $0 \%$ SFM through $34.8 \%$ SFM) for 162 days

\begin{tabular}{lcccc}
\hline \multirow{2}{*}{ Parameter } & \multicolumn{3}{c}{ Diet } \\
\cline { 2 - 5 } & 0 SFM $[n=4]$ & 11.7 SFM $[n=4]$ & 23.5 SFM $[n=4]$ & 34.8 SFM $[n=4]$ \\
\hline Iw [g] & $106 \pm 0.90$ & $105 \pm 0.90$ & $105 \pm 0.90$ & $106 \pm 0.90$ \\
FW [g] & $266 \pm 9.70$ & $253 \pm 9.77$ & $265 \pm 9.49$ & $262 \pm 9.52$ \\
SGR $^{1}$ & $0.69 \pm 0.03$ & $0.65 \pm 0.03$ & $0.69 \pm 0.03$ & $0.68 \pm 0.03$ \\
WG $[\%]_{\text {FI }^{2}}$ & $150 \pm 8.91$ & $142 \pm 8.91$ & $152 \pm 8.91$ & $147 \pm 8.91$ \\
FCR $^{3}\left(\times 10^{-3}\right)$ & $1.74^{\mathrm{a}} \pm 0.04$ & $1.67^{\mathrm{ab}} \pm 0.04$ & $1.65^{\mathrm{ab}} \pm 0.04$ & $1.52^{\mathrm{b}} \pm 0.04$ \\
$\mathrm{PER}^{4}$ & $3.04 \pm 0.19$ & $2.85 \pm 0.19$ & $2.63 \pm 0.19$ & $2.56 \pm 0.19$ \\
$\mathrm{TCG}^{5}$ & $0.78 \pm 0.03$ & $0.83 \pm 0.03$ & $0.91 \pm 0.03$ & $0.96 \pm 0.04$ \\
$\mathrm{CF}^{6}$ & $1.15 \pm 0.05$ & $1.1 \pm 0.05$ & $1.16 \pm 0.05$ & $1.13 \pm 0.05$ \\
$\mathrm{HSI}^{7}$ & $1.93 \pm 0.05$ & $1.95 \pm 0.05$ & $1.91 \pm 0.05$ & $1.95 \pm 0.05$ \\
$\mathrm{VSI}^{8}$ & $1.24^{\mathrm{a}} \pm 0.47$ & $1.30^{\mathrm{a}} \pm 0.50$ & $1.08^{\mathrm{ab}} \pm 0.47$ & $0.98^{\mathrm{b}} \pm 0.47$ \\
$\mathrm{MFI}^{9}$ & $5.3 \pm 0.26$ & $5.62 \pm 0.28$ & $5.69 \pm 0.26$ & $5.38 \pm 0.26$ \\
\hline
\end{tabular}

Each value is the mean \pm SEM of data from quadruplicate groups; The data in the same row with different superscripts differ at $P<0.05$; Data on CF, his, and MFI indices were calculated from 16 fish. Initial weight in each phase was considered as co-variables for the final weight (Fw) and SGR; ${ }^{1}$ Specific growth rate $\left(\% /\right.$ day): SGR $=100 \times \ln ($ final weight $/$ initial weight $) /$ day; ${ }^{2}$ Feed intake ratio $\left(\mathrm{g} / 100 \mathrm{~g}\right.$ fish / day): $\mathrm{FI}=100 \times$ feed consumption / average biomass $\times$ day; ${ }^{3}$ Feed conversion ratio: $\mathrm{FCR}=$ feed offered $/$ biomass gained; ${ }^{4}$ Protein efficiency ratio: PER = biomass gained / protein offered; ${ }^{5}$ Thermal coefficient of growth: TCG $=1000 \times$ $\left[\mathrm{Fw}^{1 / 3}-\mathrm{Iw}^{1 / 3}\right] /\left(\mathrm{T}^{\mathrm{o}}-\right.$ minimum $\mathrm{T}^{\mathrm{o}}$ to feed $\times$ day $) ;{ }^{6}$ Condition factor: $\mathrm{CF}=100 \times\left(\right.$ body weight $/$ total length $\left.{ }^{3}\right) ;{ }^{7}$ Hepatosomatic index: $\mathrm{HSI}=100 \times($ liver weight $/$ body weight $) ;{ }^{8}$ Viscerosomatic index: VSI $=100 \times($ visceral weight $/$ fish weight $) ;{ }^{9}$ Mesenteric fat index: $\mathrm{MFI}=100 \times($ mesenteric fat weight /body weight]; All weights are in g, length in $\mathrm{cm}$; Iw = initial weight; FW= final weight; SFM $=$ sunflower meal. 
level and a lower CL content when compared to other experimental groups. Furthermore, the ash content was slightly diminished when the SFM inclusion was increased $(P<0.05)$.

Comparing the EAA composition in whole fish bodies, the only statistical difference was found in the leucine content. Similar to $\mathrm{CP}$ contents, the fish fed diet with $11.7 \%$ SFM had the lowest leucine level $\left(1.26 \mathrm{~g} \cdot 100 \mathrm{~g}^{-1}\right.$ ww) when compared to fish subjected to the other treatments. The other EEAs were present in the same quantity in whole fish bodies, except for lysine. Lysine levels were slightly reduced when the SFM inclusion was increased while there was an increase in EAA when compared to the initial fish body values (Table 4).
In corporal retention-crude protein efficiency (CPE) and gross energy efficiency (GEE), there were no statistical differences among treatments. In both retention parameters, however, there was a slight increment as vegetal meal increased. In EEA retention, there were no statistical differences among treatments although an increment in arginine, threonine, and phenylalanine contents was observed as the SFM inclusion increased. In contrast, the lysine content diminished while the SFM inclusion increased. However, a fluctuation in valine, methionine, isoleucine, and leucine was observed among treatments while histidine levels were similar in all treatments (Table 4).

Table 4

Proximate composition, essential-amino-acid composition, and retention of sharpsnout seabream, Diplodus puntazzo, carcasses at the end of experiment

\begin{tabular}{|c|c|c|c|c|c|c|}
\hline & \multicolumn{5}{|c|}{ Diet } \\
\hline & & Initial & 0 SFM & 11.7 SFM & 23.5 SFM & 34.8 SFM \\
\hline \multicolumn{2}{|c|}{ Moisture [\%] } & 65.00 & $63.61 \pm 0.47$ & $64.54 \pm 0.47$ & $64.21 \pm 0.47$ & $64.58 \pm 0.47$ \\
\hline \multicolumn{2}{|c|}{ Crude protein $[\% \mathrm{ww}]$} & 17.44 & $18.41^{b} \pm 0.14$ & $17.78^{\mathrm{a}} \pm 0.14$ & $18.16^{\mathrm{ab}} \pm 0.14$ & $18.15^{\mathrm{ab}} \pm 0.14$ \\
\hline \multicolumn{2}{|c|}{ Crude lipid [\%ww] } & 13.06 & $13.77 \pm 0.52$ & $13.13 \pm 0.52$ & $13.67 \pm 0.52$ & $12.61 \pm 0.52$ \\
\hline \multicolumn{2}{|c|}{ Ash $[\% w w]$} & 4.28 & $4.22 \pm 0.15$ & $4.10 \pm 0.15$ & $3.89 \pm 0.15$ & $3.98 \pm 0.15$ \\
\hline \multirow{9}{*}{ 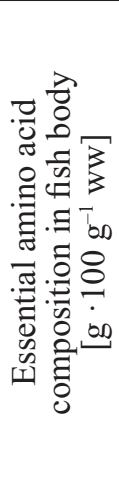 } & Histidine & 0.45 & $0.56 \pm 0.02$ & $0.49 \pm 0.02$ & $0.53 \pm 0.02$ & $0.52 \pm 0.02$ \\
\hline & Arginine & 1.49 & $1.78 \pm 0.05$ & $1.68 \pm 0.05$ & $1.69 \pm 0.05$ & $1.76 \pm 0.05$ \\
\hline & Threonine & 0.76 & $0.93 \pm 0.03$ & $0.90 \pm 0.03$ & $0.91 \pm 0.03$ & $0.93 \pm 0.03$ \\
\hline & Valine & 0.83 & $0.86 \pm 0.01$ & $0.82 \pm 0.01$ & $0.84 \pm 0.01$ & $0.83 \pm 0.01$ \\
\hline & Methionine & 0.40 & $0.47 \pm 0.01$ & $0.46 \pm 0.01$ & $0.47 \pm 0.01$ & $0.48 \pm 0.01$ \\
\hline & Lysine & 1.45 & $1.45 \pm 0.04$ & $1.41 \pm 0.04$ & $1.39 \pm 0.04$ & $1.41 \pm 0.04$ \\
\hline & Isoleucine & 0.73 & $0.70 \pm 0.01$ & $0.68 \pm 0.01$ & $0.70 \pm 0.01$ & $0.70 \pm 0.01$ \\
\hline & Leucine & 1.26 & $1.33^{b} \pm 0.01$ & $1.26^{\mathrm{a}} \pm 0.01$ & $1.30^{\mathrm{ab}} \pm 0.01$ & $1.31^{\mathrm{ab}} \pm 0.01$ \\
\hline & Phenylalanine & 0.70 & $0.82 \pm 0.03$ & $0.76 \pm 0.03$ & $0.84 \pm 0.03$ & $0.83 \pm 0.03$ \\
\hline \multicolumn{2}{|c|}{ EAA/NEAA } & 0.87 & 0.90 & 0.89 & 0.92 & 0.92 \\
\hline \multirow{2}{*}{$\begin{array}{c}\text { Retentior } \\
\text { values }\end{array}$} & $\mathrm{CPE}^{1}[\%]$ & & $13.60 \pm 1.12$ & $13.41 \pm 1.12$ & $14.88 \pm 1.12$ & $15.40 \pm 1.12$ \\
\hline & $\mathrm{GEE}^{2}[\%]$ & & $14.50 \pm 1.38$ & $14.26 \pm 1.38$ & $16.11 \pm 1.38$ & $15.71 \pm 1.38$ \\
\hline \multirow{9}{*}{ 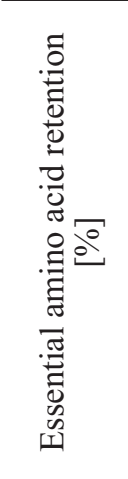 } & Histidine & & $10.76 \pm 1.53$ & $10.71 \pm 1.87$ & $9.93 \pm 1.87$ & $10.35 \pm 1.53$ \\
\hline & Arginine & & $11.60 \pm 1.59$ & $12.23 \pm 1.59$ & $12.33 \pm 2.76$ & $13.92 \pm 1.59$ \\
\hline & Threonine & & $9.44 \pm 1.33$ & $11.87 \pm 1.53$ & $10.22 \pm 1.53$ & $11.90 \pm 1.33$ \\
\hline & Valine & & $5.42 \pm 1.07$ & $7.66 \pm 1.07$ & $4.18 \pm 1.07$ & $6.24 \pm 1.07$ \\
\hline & Methionine & & $7.68 \pm 1.58$ & $9.97 \pm 1.12$ & $7.09 \pm 1.29$ & $10.41 \pm 1.12$ \\
\hline & Lysine & & $9.12 \pm 2.72$ & $8.85 \pm 1.36$ & $5.81 \pm 1.92$ & $6.94 \pm 1.57$ \\
\hline & Isoleucine & & $4.18 \pm 1.30$ & $6.57 \pm 1.06$ & $4.42 \pm 1.83$ & $6.52 \pm 1.30$ \\
\hline & Leucine & & $5.75 \pm 1.16$ & $8.14 \pm 1.16$ & $5.16 \pm 1.16$ & $7.79 \pm 1.16$ \\
\hline & Phenylalanine & & $8.78 \pm 1.48$ & $8.55 \pm 1.71$ & $9.61 \pm 1.71$ & $10.56 \pm 1.48$ \\
\hline
\end{tabular}

Values are the means $\pm \operatorname{SEM}(n=4)$; The means followed by the same superscript do not differ $(P<0.05$; Newman-Keuls $)$; EAA $=$ essential amino acids; NEAA = non essential amino acids; $\mathrm{CPE}=$ crude protein efficiency; GEE = gross energy efficiency; ${ }^{1}$ Crude protein efficiency: CPE $(\%)=($ fish protein gain $[\mathrm{g}]) \times 100 /($ protein intake $[\mathrm{g}]) ;{ }^{2}$ Gross energy efficiency: GEE $(\%)=$ $($ fish energy gain $[\mathrm{kJ}]) \times 100 /($ energy intake $[\mathrm{kJ}]) ; \mathrm{SFM}=$ sunflower meal. 


\section{DISCUSSION}

The amino acid profile of all experimental diets was well balanced, which was similar to the profile reported by Aas et al. (2006) who included up to $36 \%$ bacterial protein meal in Salmo salar. They reported good final fish growth at the end of experimental period, attributing these results to well balanced amino acids in the experimental diets. In addition, Mai et al. (2006) indicated that lysine is the most limiting amino acid in ingredients used for production of commercial fish feeds, especially when fish meal is replaced by plant protein sources. In their study, the lysine ranged from 3.72 to $2.95 \mathrm{~g} \cdot \mathrm{kg}^{-1}$. Nevertheless, sharpsnout seabream growth rates were not as good when compared with other fattening experiments where better growth values were obtained in a shorter period of time in this species (Orban et al. 2000, Hernández et al. 2007). One possible reason for the lower growth in our study may be explained by the temperature regime because the heat pump was broken for the final two months of the study and the temperature dropped from 27.4 to $18.1^{\circ} \mathrm{C}$.

In sharpsnout seabream, the growth parameters were not affected by SFM inclusion even with the high level of CF present in the experimental diets, especially in the diets with $23.5 \%$ and $34.8 \%$ SFM inclusion. It was possible that the omnivorous habits of the sharpsnout seabream enabled this species to accept a diet with up to $7 \% \mathrm{CF}$ content without affecting their final growth. Similar results were presented by Gill et al. (2006) who substituted fish meal with 33\% dehulled SFM in Salmo salar although these authors only reported $3.65 \% \mathrm{CF}$ in the maximal inclusion. Mena Sellés and García García (2002) reported that one of the preferred foods of D. puntazzo, especially in autumn and winter, was algae. According to Lahaye (1991), algae have high fibre contents (32.7\%-74.6\% DM). Moreover, the sharpsnout seabream gut is longer than the gut found in other species from the same genera, such as D. sargus and D. vulgaris, which may be the reason why this fish was not affected by the high fibre content in the experimental diets. Furthermore, Tramati et al. (2005) found an enzymatic pattern that is well suited to protein digestion but also has a high potential for digesting vegetal polysaccharides, which is in agreement with its omnivorous habits.

On the other hand, Sánchez Lozano et al. (2007) assayed a maximal SFM inclusion of 36\% in Sparus aurata and were only able to replace fish meal with $12 \%$ as a maximal inclusion without affecting fish growth. At the same time, Olvera-Novoa et al. (2002) were only able to obtain a $20 \%$ SFM inclusion without statistical differences in Tilapia rendalli, whereas Furuya et al. (2000) recommended $14 \%$ as a maximal replacement for juvenile Nile tilapia. Regarding feed efficiency parameters, Sánchez Lozano et al. (2007) showed an increment in FI whereas Olvera Novoa et al. (2002) reported a reduction in FI as the SFM substitution increased. Gill et al. (2006) reported similar results to our study with regard to PER.

Another important fact to consider is the solitary behaviour of sharpsnout seabream in nature, especially in mature animals (Harmelin-Vivien et al. 1995, Macpherson 1998). Monoculture conditions give rise to competition for food and space with increasing aggressiveness and a reduction in biomass (Karakatsouli et al. 2006). This competition for food and space was observed throughout this trial, which may have been an additional cause of the low growth rates achieved at the end of the experimental period.

On the other hand, an optimal amino acid profile in experimental diets may have not allowed homogeneous growth, feed conversion ratio (FCR) and PER with a reduction of FIR. Furuya et al. (2000) suggested that better fish growth and efficiency was related to a well balanced amino acid profile. In addition, Gill et al. (2006) did not report statistical differences in FI, but they did report an increase in FI as the SFM inclusion increased.

In biometric parameters, the reduction in HIS and MFI may have been partially caused by the CF in experimental diets. In addition, D. puntazzo starts its reproduction activity between October and December (Hernández 2006, Papadaki et al. 2008), and these fish may use their reserves (fat and glycogen), energy and nutrients for gonad development instead of retaining their reserves in visceral fat or liver, which may also affect fish growth in later months.

In body composition, only fish fed diet with $11.7 \%$ SFM inclusion obtained the lowest value in CP indicating that the vegetal meal did not affect body composition, which was similar to the results of Gill et al. (2006) and Sánchez Lozano et al. (2007) results. However, OlveraNovoa et al. (2002) obtained statistical differences not only in CP but also in CL, ash and humidity as a consequence of SFM inclusion leading to a reduction of $\mathrm{CP}$ and an increase in CL and ash content.

Leucine was the only EAA that presented a statistical difference, with the lowest value presented in $11.7 \%$ SFM inclusion. According to Choo et al. (1991), the excess EAA increased feed efficiency but depressed FI, growth and protein deposition of rainbow trout. In general, SFM inclusion did not alter EAAs in carcasses, especially lysine that is known to affect fish growth and health (Mai et al. 2006), allowing a uniform fish growth among treatments. Similar results were reported by Helland and Grisdale-Helland (2006). However, Olvera-Novoa et al. (2002) and Gómez-Requeni et al. (2004) attributed growth reduction to the amino acid deficiency.

The EAA retention found in our study was low in comparison with rates reported by Helland et al. (2006) and Aas et al. (2006). This difference may be due to the high FI in relation to low final fish growth achieved at the end of the experiment. Moreover, there was a fluctuation in amino acid retention in different treatments, which may have been a response by inner fish metabolism to equilibrate EAA content in their bodies according to their needs. According to Li et al. (2009), amino acids have important and versatile roles in fish nutrition and metabolism. The functions of amino acids include the following: appetite stimulation (alanine, glutamate, proline, and serine); growth and development regulation (arginine, glutamine, and leucine); and dietary supplementation of amino 
acids (lysine, methionine, threonine, and tryptophan) to compensate for their deficiencies in plant feedstuffs. In the case of SFM, the EAA retention rates were not affected even with the highest inclusion (34.8\%).

\section{CONCLUSION}

The maximal SFM inclusion (34.8\%) did not alter growth parameters, nutritive parameters or amino acid profiles in sharpsnout seabream, even in diets with the highest CF content $(23.5 \%$ and $34.8 \%$ SFM). It was possible that the natural feeding habits of sharpsnout seabream enable the fish to accept a diet with a CF level over $7 \%$ without affecting the final weight. The low growth found in all treatments may have been attributed to several factors that should be further investigated.

\section{ACKNOWLEDGEMENT}

This research was supported by grants from the Planes Nacionales de Acuicultura (JACUMAR).

\section{REFERENCES}

Aas T.S., Hatlen B., Grisdale-Helland B., Terjesen B.F., Bakke-McKellep A.M., Helland S.J. 2006. Effects of diets containing a bacterial protein meal on growth and feed utilisation in ranbow trout (Oncorhynchus mykiss). Aquacutlure 261 (1): 357-368. DOI: 10.1016/j.aquaculture.2006.07.033.

Ahmad T., Aslam Z., Rasool S. 2004. Reducing fiber content of sunflower oil meal through treatment of enzymes produced from Arachnoitus sp. Animal Science Journal 75 (3): 231-235. DOI: 10.1111/j.1740-0929.2004.00181.x.

Anonymous 1990. Official methods of analysis. Association of Official Analytical Chemists (AOAC). Arlington, VA, USA.

Bosch L., Alegría A., Farré R. 2006. Application of the 6aminoquinolyl- $N$-hydroxysuccinimidyl carbamate (AQC), reagent to the RP-HPLC determination of amino acids in infant foods. Journal of Chromatography B 831 (1-2): 176-183. DOI: 10.1016/j.jchromb.2005.12.002.

Chatzifotis S., Esteban A.G., Divanach P. 2006. Fishmeal replacements by alfalfa protein concentrate in sharp snout sea bream Diplodus puntazzo. Fisheries Science 72 (6): 1313-1315. DOI: 10.1111/j.1444-2906.2006.01290.x.

Choo P.-S., Smith T.K., Cho C.Y., Ferguson H.W. 1991. Dietary excesses of leucine influence growth and body composition of rainbow trout. Journal of Nutrition 121 (12): 1932-1939.

Francis G., Makker H.P.S., Becker K. 2001. Antinutritional factors present in plant-derived alternate fish feed ingredients and their effects in fish. Aquaculture 199 (3-4): 197-227. DOI: 10.1016/S0044-8486(01)00526-9.

Furuya V.R.B., Furuya W.M., Hayashi C., Soares C.M. 2000. Niveles de inclusión de harina de girasol en la alimentación de la tilapia del Nilo (Oreochromis niloticus), en etapa juvenil. [Inclusion levels of sunflower meal in diets for juvenile Nile tilapia (Oreochromis niloticus).] Zootecnia Tropical 18 (1): 91-106.

Gandhi A.P., Jha K., Gupta V. 2008. Technical paper studies on the production of defatted sunflower meal with low polyphenol and phytate contents and its nutritional profile. ASEAN Food Journal 15 (1): 97-100.
Gill N., Higgs D.A., Skura B.J., Rowshandeli M., Dosanjh B.S., Mann J., Gannam A.L. 2006. Nutritive value of partially dehulled and extruded sunflower meal for post-smolt Atlantic salmon (Salmo salar L.) in sea water. Aquaculture Research 37 (13): 1348-1359. DOI: 10.1111/j.1365-2109.2006.01567.x.

Gómez-Requeni P., Mingarro M., Calduch-Giner J.A., Médale F., Martin S.A.M., Houlihan D.F., Kaushik S., Pérez-Sánchez J. 2004. Protein growth performance, amino acid utilisation and somatotropic axis responsiveness to fish meal replacement by plant protein sources in gilthead sea bream (Sparus aurata). Aquaculture 232 (1-4): 493-510. DOI: 10.1016/S0044-8486(03)00532-5.

Harmelin-Vivien M.L., Harmelin J.G., Leboulleux V. 1995. Microhabitat requirements for settlement of juvenile sparid fishes on Mediterranean rocky shores. Hydrobiologia 300-301 (1): 309-320. DOI: 10.1007/BF00024471.

Helland S.J., Grisdale-Helland B. 2006. Replacement of fish meal with wheat gluten in diets for Atlantic halibut (Hippoglossus hippoglossus): Effect on whole-body amino acid concentrations. Aquaculture 261 (4): 1363-1370. DOI: 10.1016/j.aquaculture.2006.09.025.

Hernández M.D. 2006. El cultivo de una especie omnívora: el sargo picudo (Diplodus puntazzo). [The production of an omnivorous species: sharpsnout seabream (Diplodus puntazzo).] Pp. 99-114. In: Zamora S., Martínez F.J., Cruz V. (eds.) Acuicultura III: Cultivo y Alimentación de peces. Universidad Internacional del Mar, Murcia, Spain.

Hernández M.D., Martínez F.J., Jover M., García García B. 2007. Effects of partial replacement of fish meal by soybean meal in sharpsnout seabream (Diplodus puntazzo) diet. Aquaculture 263 (1-4): 159-167. DOI: 10.1016/j.aquaculture.2006.07.040.

Karakatsouli N., Papafotiou P., Papoutsoglou S.E., 2006. Mono- and duoculture of juvenile sharpsnout seabream Diplodus puntazzo (Cetti) and gilthead seabream Sparus aurata $\mathrm{L}$. in a recirculated water system. Aquaculture Research 37 (16): 1654-1661. DOI: 10.1111/j.1365-2109.2006.01612.x.

Lahaye M. 1991. Marine algae as sources of fibres: Determination of soluble and insoluble dietary fibre contents in some 'sea vegetables'. Journal of the Science of Food and Agriculture 54 (4): 587-594. DOI: 10.1002/jsfa.2740540410.

Li P., Mai K., Trushenski J., Wu G. 2009. New developments in fish amino acid nutrition: Towards functional and environmentally oriented aquafeeds. Amino Acids 37 (1): 43-53. DOI: 10.1007/s00726-008-0171-1.

Macpherson E. 1998. Ontogenetic shifts in habitat use and aggregation in juvenile sparid fishes. Journal of Experimental Marine Biology and Ecology 220 (1): 127-150. DOI: 10.1016/S0022-0981(97)00086-5.

Mai K., Zhang L., Ai Q., Duan Q., Zhang C., Li H., Wan J., Liufu Z. 2006. Dietary lysine requirement of juvenile Japanese seabass, Lateolabrax japonicus. Aquaculture 258 (1-4): 535-542. DOI: 10.1016/j.aquaculture.2006.04.043.

Maina J.G., Beames R.M., Higgs D., Mbugua P.N., Iwama G., Kisia S.M. 2003. Partial replacement of fishmeal with sunflower cake and corn oil in diets for tilapia Oreochromis niloticus (Linn): Effect on whole body fatty acids. Aquaculture Research 34 (8): 601-608.

DOI: $10.1046 /$ j.1365-2109.2003.00848.x. 
Martínez C.A. 1984. Advances in the substitution of fish meal and soybean meal by sunflower meal in diets of rainbow trout (Salmo gairdneri L.). Anales Del Instituto De Ciencias Del Mar Y Limnología Univ. Nacional. Autónoma México 13 (2): 345-350. http://biblioweb.dgsca.unam.mx/cienciasdelmar/instituto/19862/ /articulo235.html.

Mena Sellés C., García García B. 2002. Importancia de la proteína vegetal en la dieta natural de poblaciones salvajes de Sargo picudo Diplodus puntazzo (Cetti, 1777); sus implicaciones en el cultivo intensivo. [Importance of vegetable protein in natural diet of wild population of sharpsnout seabream (Diplodus puntazzo); and its implication in intensive culture.] AquaTIC: Revista Electrónica de Acuicultura. Tecnología e Investigación en Castellano (17): (no page numbering)

http://www.revistaaquatic.com/aquatic/html/art1705/sargo.htm.

Olvera-Novoa M., Olivera-Castillo L. Martínez-Palacios C.A. 2002 Sunflower seed meal as a protein source in diets for Tilapia rendalli (Boulanger 1896) fingerlings. Aquaculture Research 33 (3): 223-229. DOI: 10.1046/j.1365-2109.2002.00666.x.

Orban E., Di Lena G., Ricelli A., Paoletti F., Casini I., Gambelli L., Caproni R. 2000. Quality characteristics of sharpsnout sea bream (Diplodus puntazzo) from different intensive rearing systems. Food Chemistry 70 (1): 27-32. DOI: 10.1016/S0956-7135(99)00112-7.

Papadaki M., Papadopoulou M., Siggelaki I., Mylonas C.C. 2008. Egg and sperm production and quality of sharpsnout sea bream (Diplodus puntazzo) in captivity. Aquaculture 276 (1-4): 187-197. DOI: 10.1016/j.aquaculture.2008.01.033.

Rondán M., Hernández M.D., Egea M.A., García B., Jover M., Rueda F.M., Martínez F.J. 2004. Effects of fishmeal replacement with soybean meal as protein source, and protein replacement with carbohydrates as an alternative energy source on sharpsnout sea bream, Diplodus puntazzo, fatty acid profile. Aquaculture Research 35 (13): 1220-1227. DOI: $10.1111 / \mathrm{j} .1365-2109.2004 .01130 . x$.

Sánchez Lozano N.B., Tomás Vidal A., Martínez-Llorens S., Nogales Mérida S., Espert Blanco J., Moñino López A., Pla Torres M., Jover Cerdá M. 2007. Growth and economic profit of gilthead sea bream (Sparus aurata L.) fed sunflower meal. Aquaculture 272 (1-4): 528-534. DOI: 10.1016/j.aquaculture.2007.07.221.

Sanz A., Morales A.E., De la Higuera M., Gardenete G. 1994. Sunflower meal compared with soybean meals as partial substitutes for fish meal in rainbow trout (Oncorhynchus mykiss) diets: protein and energy utilization. Aquaculture 128 (3-4): 287-300. DOI: 10.1016/0044-8486(94)90318-2.

Snedecor G., Cochran W. 1971. Statistical methods. The Iowa State University Press, Ames, IA, USA.

Tramati C., Savona B., Mazzola A. 2005. A study of the pattern of digestive enzimes in Diplodus puntazzo (Cetti, 1777) (Osteichhyes, Sparidae): Evidence for the definition of nutritional protocols. Aquaculture International 13 (1-2): 89-95. DOI: 10.1007/s10499-004-9028-0.

Received: 2 April 2009

Accepted: 1 June 2010

Published electronically: 25 March 2011 